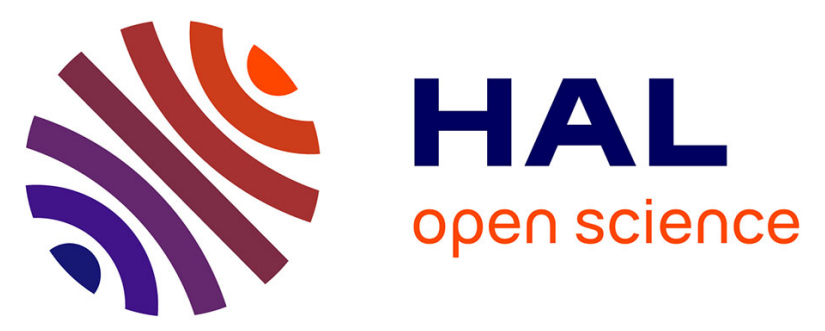

\title{
Polycyclic aromatic hydrocarbons potentiate high-fat diet effects on intestinal inflammation
}

Ayman Khalil, Pierre-Henri Villard, Anh Dao Maih, Rémy Burcelin, Serge Champion, Francis Fouchier, Jean-François Savouret, Yves Barra, Eric Sérée

\section{- To cite this version:}

Ayman Khalil, Pierre-Henri Villard, Anh Dao Maih, Rémy Burcelin, Serge Champion, et al.. Polycyclic aromatic hydrocarbons potentiate high-fat diet effects on intestinal inflammation. Toxicology Letters, 2010, 196 (3), pp.161-167. 10.1016/j.toxlet.2010.04.010 . hal-01773756

\section{HAL Id: hal-01773756 \\ https://hal.science/hal-01773756}

Submitted on 18 May 2018

HAL is a multi-disciplinary open access archive for the deposit and dissemination of scientific research documents, whether they are published or not. The documents may come from teaching and research institutions in France or abroad, or from public or private research centers.
L'archive ouverte pluridisciplinaire HAL, est destinée au dépôt et à la diffusion de documents scientifiques de niveau recherche, publiés ou non, émanant des établissements d'enseignement et de recherche français ou étrangers, des laboratoires publics ou privés. 


\title{
HAL \\ archives-ouvertes
}

\section{Polycyclic aromatic hydrocarbons potentiate high-fat diet effects on intestinal inflammation}

\author{
Ayman Khalil, Pierre-Henri Villard, Maih Dao, Rémy Burcelin, Serge
}

Champion, Francis Fouchier, Jean-François Savouret, Yves Barra, Eric Sérée, Maih AnhDao

\section{To cite this version:}

Ayman Khalil, Pierre-Henri Villard, Maih Dao, Rémy Burcelin, Serge Champion, et al.. Polycyclic aromatic hydrocarbons potentiate high-fat diet effects on intestinal inflammation. Toxicology Letters, Elsevier, 2010, 196 (3), pp.161-167. <10.1016/j.toxlet.2010.04.010>. <hal-01773756>

\section{HAL Id: hal-01773756 \\ https://hal.archives-ouvertes.fr/hal-01773756}

Submitted on 18 May 2018

HAL is a multi-disciplinary open access archive for the deposit and dissemination of scientific research documents, whether they are published or not. The documents may come from teaching and research institutions in France or abroad, or from public or private research centers.
L'archive ouverte pluridisciplinaire HAL, est destinée au dépôt et à la diffusion de documents scientifiques de niveau recherche, publiés ou non, émanant des établissements d'enseignement et de recherche français ou étrangers, des laboratoires publics ou privés. 


\section{Polycyclic aromatic hydrocarbons potentiate high-fat diet effects on intestinal inflammation and type 2 diabetes}

KHALIL $^{1}$ Ayman, VILLARD ${ }^{1 \Xi}$ Pierre-Henri, MAIH ${ }^{1}$ Anh Dao, BURCELIN ${ }^{2}$ Rémy,

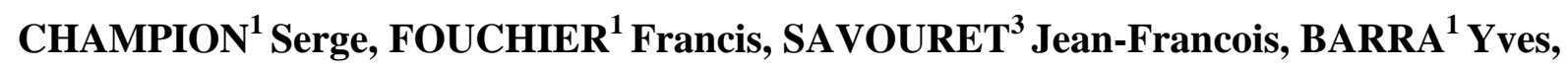
SEREE $^{1}$ Eric

${ }^{1}$ INRA, UMR1260 Nutriments Lipidiques et Prévention des Maladies Métaboliques, Université de la Méditerranée, 27 boulevard Jean-Moulin, Marseille, F-13385, France;

${ }^{2}$ INSERM U858 Institute of Molecular Medicine, IFR31, Rangueil Hospital, Toulouse, France

${ }^{3}$ UMR-747-Inserm; Université Paris Descartes, UFR Biomédicale, 45 rue des Saints-Pères 75006 Paris, France

[E Corresponding authors. Email addresses eric.seree@pharmacie.univ-mrs.fr (E. Seree); pierre-henri.villard@pharmacie.univ-mrs.fr (PH Villard) Tel/Fax: (33) 491835594 


\begin{abstract}
We demonstrate that intestinal inflammation caused by the environmental contaminant benzo $[a]$ pyrene increases the risk of developing type 2 diabetes. Our in vivo results indicate that a high-fat diet (HFD) induces a pre-diabetic state in mice compared with animals fed normal chow. HFD increased IL-1ßmRNA concentration in the jejunum, colon, and liver, and TNF $\alpha$ was increased in the colon and strongly increased in the liver. HFD also increased the expression of other genes related to type 2 diabetes, such as the uncoupling protein UCP2, throughout the bowel and liver, but not in the colon. The treatment of HFD with $\mathrm{BaP}$ enhanced the expression of IL-1 $\beta$ in the liver and TNF $\alpha$ throughout the bowel and in the liver. Adding $\mathrm{BaP}$ to the diet also caused a significant decrease in the expression of the incretin glucagon-like peptide 1, which plays an important role in insulin secretion. Our results suggest that intestinal inflammation may be involved in the onset of type 2 diabetes and that chronic exposure to environmental polycyclic aromatic hydrocarbons can increase the risk of type 2 diabetes by inducing pro-inflammatory cytokine production.
\end{abstract}

Key words: Inflammation, high-fat diet, polycyclic aromatic hydrocarbon, benzo(a)pyrene, type 2 diabetes, GLP-1 


\section{Introduction}

Polycyclic aromatic hydrocarbons (PAHs) such as benzo[a]pyrene (BaP) are major environmental contaminants. PAHs are generated primarily from incomplete combustion of organic materials and are found in charcoal-barbecued foods. Mainly through the Ah receptor (AhR) signaling pathway, PAHs regulate the expression of several genes including proinflammatory cytokines. Cells exposed to PAHs overexpressed IL-1 $\beta$, IFN $\gamma$ and IL-8 [1,2,3]. Similar results were obtained with other AhR ligands, such as dioxins, which trigger the induction of IL-1 $\beta$ and TNF $\alpha$ in hepatic inflammation.

Several studies have shown that cigarette smoking increases the risk of type 2 diabetes (T2D) [4]. Smokers are more resistant than non-smokers to insulin-mediated glucose uptake and more hyperinsulinemic in response to an oral glucose load [5]. In the same way, persons exposed to dioxins or polychlorobiphenyls (PCBs) are at higher risk for metabolic diseases such as T2D [6]. Dioxins and PCBs are also well-known AhR ligands [7], and are present at various levels in food.

Most people with T2D are overweight, have low physical activity, and have relatives with diabetes. Poor dietary habits are definitely considered as a major risk factor responsible for the increased occurrence of diabetes today [8]. Several studies have shown that inflammation is closely correlated with the development of T2D [9], as attested by the high plasma concentration of C-reactive protein CRP and pro-inflammatory cytokines IL-6 and TNF $\alpha$ [10]. Hence both genetic and environmental factors, such as diet, physical inactivity, smoking and oxidative stress are responsible for the initiation and progression of chronic inflammation [11]. The origin of the inflammation is unknown, but a recent original hypothesis suggested that high-fat diet-induced obesity was associated with gut inflammation and with a modification of the gut microflora [12,13].

We hypothesized that $\mathrm{BaP}$ could potentiate the development of HFD-induced T2D through the modulation of the expression of genes implicated in inflammatory response and oxidative balance in the bowel. The aim of the present study was therefore to investigate the effects of $\mathrm{BaP}$ in the context of high-fat diet-induced diabetes on gut inflammation and its influence on the development of T2D. 


\section{Materials and methods}

\section{Animal preparation and treatment}

Four- to five-week-old male C57B6/6J mice (IFFACREDO, L'Arbresle, France) were maintained on three types of diet: a normal chow diet (NC, energy content: 12\% fat, 28\% protein, and 60\% carbohydrate), a high-fat diet (HFD) (energy content: $72 \%$ fat comprising corn oil and lard, $28 \%$ protein, and $<1 \%$ carbohydrate), as described [14], and a high-fat diet supplemented with benzo[ $[a]$ pyrene $(\mathrm{BaP}, 2.5 \mathrm{mg} / \mathrm{kg}$ bw) for 5 weeks. Ten mice per cage were kept under an 8 am-to- 8 pm dark cycle. Blood was collected at $2 \mathrm{pm}$ in the fed state. For fasting experiments and blood sampling, food was removed at $8 \mathrm{pm}$, and the mice were kept in a new clean cage for $6 \mathrm{~h}$. During the study, food intake, weight gain and glycemia were measured as previously described $[15,16]$.

\section{Intraperitoneal glucose tolerance test}

An intraperitoneal glucose tolerance test (IPGTT), ) was given to $6 \mathrm{~h}$-fasted mice after one month ( 5 weeks) of diet treatment (intraperitoneal injection of $1 \mathrm{~g} / \mathrm{kg}$ body weight of glucose). Blood glucose levels were monitored from the tip of the tail vein with a glucose meter (Roche Diagnostic, Rotkreuze, Switzerland) from a $3.5 \mu 1$ sample of tail blood at $-30,0,30,60$, and 90 min after glucose injection [17]. Areas under the curve (AUC) (-30-90) were calculated for each group HFD, HFD+BaP and the NC group.

\section{RNA extraction and real time PCR}

At the end of treatment the animals were sacrificed, and the four parts of the bowel and the liver were excised. Total RNA was isolated from the tissues using Trizol reagent (Invitrogen, France), RNA was quantified by NanoDrop (NanoDrop technologies Inc., France). Total RNA (1 $\mu \mathrm{g})$ was reverse-transcribed using Moloney murine leukemia virus reversetranscriptase (Invitrogen, Cergy-Pontoise, France) and random primers at $42{ }^{\circ} \mathrm{C}$ for $1 \mathrm{~h}$. The expression of target genes was determined using the Lightcycler 480 System (Roche, France). To avoiding pipetting errors we used a Biomek3000 pipetting robot equipped with a 96channel head (Bekman and Coulter). PCR was performed with $0.5 \mu \mathrm{M}$ of each primer and with the LightCycler and Mastermix Plus for SYBR ${ }^{\mathrm{TM}}$ GreenI No ROX, in a total volume of $10 \mu \mathrm{l}$. Cycling conditions were as follows: 10 min denaturing at $95{ }^{\circ} \mathrm{C}$, followed by 40 cycles of $30 \mathrm{~s}$ denaturing at $95{ }^{\circ} \mathrm{C}, 30 \mathrm{~s}$ primer annealing at $60{ }^{\circ} \mathrm{C}$ and $30 \mathrm{~s}$ fragment elongation at $72{ }^{\circ} \mathrm{C}$. The melting curve was analyzed with the LightCycler® 480 gene scanning software. 
Mouse IL-1 $\beta$, TNF $\alpha$, IL-10, TGF $\beta$, GLP-1, UCP2, and UPC3 expressions were normalized to

$\beta 2$-actin expression and data quantified by the method of $2^{-\Delta \Delta \mathrm{Ct}}[18]$. The primers used are listed in Table 1.

\section{Statistical analysis}

Statistical analysis was performed using the Mann-Whitney test by means of GraphPad

Software. Values were considered statistically different when $P<0$. 05. Results are presented as means $\pm \mathrm{SD}$. 


\section{Results}

We analyzed the effect of HFD compared with NC on the inflammatory state linked to type 2 diabetes. We studied, on the same genes, the effect of a supplementation of HFD with BaP (HFD+BaP) compared with the HFD alone. The tissues studied were the segmented bowel (duodenum, jejunum, ileum and colon) and the liver.

\section{Effect of HFD versus NC diet on the intestinal and hepatic expression of some target genes (Fig. 1)}

We observed a significant induction by HFD of pro-inflammatory IL- $1 \beta$ gene expression in the jejunum (2.8-fold) and colon (1.8-fold).

We also analyzed the gene expression of another pro-inflammatory cytokine, TNF $\alpha$. TNF $\alpha$ was only significantly induced in the colon (1.7-fold). In the liver, the gene expression of both cytokines IL-1 $\beta$ and TNF $\alpha$ were strongly induced by the HFD (2.8-fold and 13.9-fold respectively).

To check the anti-inflammatory response, the expression of TGF $\beta$ and IL-10 genes was analyzed. The results indicate that in the bowel, TGF $\beta$ expression was significantly induced in the jejunum (1.7-fold) and colon (1.5-fold) similarly to what was observed for IL-1 $\beta$. No significant variation in TGF $\beta$ expression was observed in the duodenum or ileum. The expression of IL-10, which plays an important role in the inflammatory homeostasis of the bowel, was also analyzed. This anti-inflammatory cytokine was significantly down-regulated in the ileum (0.25-fold) and colon (0.5-fold). IL-10 gene expression was not detected in the upper bowel (duodenum and jejunum).

In the liver, we did not observe any significant variation in either TGF $\beta$ or IL-10 gene expression.

We also analyzed the expression of uncoupling proteins 2 and 3 (UCP-2 and UCP-3) involved in the oxidative status, which play an important role in metabolic syndrome [19]. The results presented indicated that UCP2 expression was significantly increased in the upper bowel, in particular in the duodenum, jejunum and ileum (3.7-, 2.5- and 1.6-fold increase respectively). In contrast, a significant decrease of UCP 2 expression was observed in the colon (0.8-fold). We also analyzed UCP3 gene expression. This gene was induced in the jejunum (2.6-fold) and ileum (1.8-fold).

In the liver, gene expression of UCP2 was significantly induced (1.9-fold). UCP3 was not detected in this tissue. 


\section{Effect of BaP added to HFD versus HFD on the intestinal and hepatic expression of some target genes (Fig 2)}

The presence of BaP in HFD did not affect HFD-induced IL-1 $\beta$ gene expression in the bowel or liver. In contrast, TNF $\alpha$ was significantly induced (around 2-fold) in all tested tissues except for the ileum.

Concerning genes associated with the anti-inflammatory response, the addition of $\mathrm{BaP}$ significantly decreased the expression of TGF $\beta$ in the ileum and slightly in the rest of the bowel. No significant variation was observed in the liver. In contrast, IL-10 expression was significantly increased in the colon (1.4-fold) and liver (2-fold).

UCP2 expression was significantly decreased in response to addition of $\mathrm{BaP}$ only in the upper bowel: duodenum (0.4-fold) and jejunum (0.7-fold). By contrast, this gene was significantly induced in the liver (2.2-fold).

No significant variation was observed in UCP3 expression in the jejunum, ileum, colon or liver.

To evaluate the physiological effects of the diet, we analyzed the glucagon-like peptide 1 incretin (GLP-1), which is known to play an essential role in insulin secretion, and the biochemical data characteristics of type 2 diabetes (food intake, weight, and IPGTT).

The results presented in Figure 1 indicate that compared with a normal diet, GLP-1 was not significantly modulated by HFD in the ileum or colon. Compared with HFD alone, the presence of $\mathrm{BaP}$ in HFD significantly decreased GLP-1 gene expression in the ileum (0.4fold) and colon (0.4-fold). No expression of this gene was found in the liver, jejunum or duodenum.

\section{Effect of HFD or BaP added to HFD on food intake}

As shown in Figure 3A, no significant variation of food intake was observed during the treatment when the HFD mice were compared with the NC diet mice. The same results were observed when the HFD+BaP mice were compared with HFD mice.

\section{Effect of HFD or BaP added to HFD on body weight gain}

As shown in Figure 3B, no significant body weight gain was observed during the treatment when the HFD mice were compared with the NC diet mice. The same results were observed when we compared the HFD+BaP group with the HFD group. 


\section{Effect of HFD or BaP added to HFD on glucose tolerance}

As shown in Figure 3C, HFD mice exhibited significant glucose intolerance when compared with the normal chow diet mice, as evidenced by the significant higher AUC calculated from glucose profiles (Fig.3D). By contrast, no significant glucose intolerance was observed when the HFD+BaP mice were compared with the HFD mice (Fig. 3C and D).

\section{Discussion}

T2D is a major public health concern. It is closely linked to obesity, and is associated with an increased risk of cardiovascular events. Although genetic predispositions to T2D have been described, environmental factors play a major role in the etiology of this metabolic disease. The influences of a hypercaloric diet associated with a decrease in physical activity have been widely described as the main factors in decreased insulin sensitivity. However, epidemiological studies have demonstrated that other environmental factors are also involved. It has now been clearly demonstrated that environmental exposure to dioxins and polychlorobiphenyls (PCB) is associated with an increased the risk of T2D and metabolic syndrome [20,21,22,23]. Similar effects have been observed in tobacco smokers [24,25,26]. Dioxins, PCBs and PAHs are well-known AhR ligands [27,28]. Although extensive data demonstrate that these chemicals enhance susceptibility to chemical carcinogenesis by inducing CYP1 expression, much recent work shows that AhR activation leads to an induction of pro-inflammatory cytokines such as IL-1 $\beta$ and TNF $\alpha[29,30]$. T2D and decreased insulin sensitivity have been associated with an increase in circulating TNF $\alpha$ levels. It is known that the increase in TNF $\alpha$ is a consequence of the inflammation of the visceral adipose tissue.

We investigated the involvement of the bowel in the nutrient-induced inflammatory response, given that this tissue has primary contact with food. We compared the response of the bowel with that of the liver.

As diabetes is known to be associated with some disturbances of inflammatory status, we analyzed the inflammatory gene expression in response to HFD, in both the bowel and the liver. The induction of inflammation following HFD is already well-documented in the liver and our results are consistent with previous published data [12, 34, 35]. In the bowel, amplitude of the inflammatory response was specific to the intestine segment considered. Alltogether, the study of intestinal IL-1 $\beta$ and TNF $\alpha$ expression shows that the response was similar to what was observed in the liver. We note that except in the colon, we found in all 
parts of the bowel an association between pro-inflammatory gene expression and UCP induction. As previously reported by others, no TGF $\beta$ or IL10-induced anti-inflammatory response was observed in the liver. However, in the jejunum and colon, but not in the duodenum or ileum, TGF $\beta$ seems to play an important role after HFD by counteracting the inflammatory process. When BaP was added to HFD, we observed an amplification of the inflammatory response in both the bowel and the liver. Compared with IL-1 $\beta$, TNF $\alpha$ appears as the main inflammatory cytokine enhanced in response to the presence of $\mathrm{BaP}$ in HFD. The HFD-induced anti-inflammatory response, represented by TGF $\beta$ expression, was reduced by $\mathrm{BaP}$ treatment in all parts of the intestine. Thus in the presence of $\mathrm{BaP}$, the HFD-induced inflammation status was amplified through both an enhancement of pro-inflammatory cytokines and a down-regulation of anti-inflammatory cytokines. This process, induced first in the intestine, may contribute to further deterioration of the metabolism. By contrast, in both the colon and the liver, HDF-induced IL-10 expression was further enhanced by addition of $\mathrm{BaP}$. In this case, the colon and liver displayed similar patterns of anti-inflammatory response. The up-regulation of IL10 we observed in the liver and colon may be the main factor that reduces the inflammatory process in these tissues. These data indicate that the bowel, the first target of food constituents, may play a role in the modulation of the inflammatory status.

We analyzed the expression of uncoupled proteins (UCP2 and UCP3), which are modulators of inflammatory response mediated by redox balance and linked to diabetes emergence. In general, in various tissues already analyzed, expression of the UCP gene family was increased by HFD. UCP2 was induced by the HFD in the main parts of the bowel comprising the duodenum, jejunum and ileum. This response is similar to that observed in the liver as reported in this work and elsewhere [31,32]. By contrast, the colon presents a different pattern of UCP2 expression, with a decrease in its expression. UCP3 was detected in the jejunum, ileum and colon with only a significant induction in the jejunum. These data are original and, to our knowledge, no data were available concerning the expression of UCP $2 / 3$ in the different parts of the bowel compared with the liver. Thus as previously reported by others in the liver [31,32,33], HFD modifies UCP2/3 expression, and this response appears to be differently regulated according to the part of intestine tested. When added to HFD, BaP partially counteracted the effect of HFD on UCP2 expression, which was found to be decreased in the upper bowel, including the duodenum and jejunum. However, this response was opposite to that of the liver, where BaP enhanced the HFD-induced UCP2 expression. Thus unexpectedly, the disturbance of metabolism induced by HFD seems to be 'normalized' 
in the bowel by $\mathrm{BaP}$ addition, but amplified in the liver. BaP induced no variation in UCP3 expression, showing that the effects of $\mathrm{BaP}$ are gene-specific.

We further analyzed the effect of HFD alone or BaP+HFD on GLP-1 expression, since it normalizes blood glucose level by increasing circulating insulin and decreasing glucagon secretion. When $\mathrm{BaP}$ was added to $\mathrm{HFD}$, we observed a significant decrease in GLP-1 expression in the bowel, particularly in the terminal parts ileum and colon. AhR ligands, acting as inflammatory compounds and decreasing GLP-1 expression may be involved in the onset of diabetes. Biochemical data (IPGTT) show that HFD treatment reduced insulin sensitivity, but BaP supplementation did not modify this effect.

Overall, our findings show that the bowel may play a role in this process.

\section{Conclusion}

Our results show that PAHs, by activating AhR, are involved in the potentiation of the inflammatory process induced by HFD. The inflammation occurs in the bowel, one of the first organs exposed to dietary constituents. This inflammation may be involved in the inflammatory stimulation of other organs such as the liver. In the bowel, the colon seems to play a specific role in this effect.

\section{References}

[1] M. Lyte, P.H. Bick, Modulation of interleukin-1 production by macrophages following benzo(a)pyrene exposure, Int. J. Immunopharmacol. 8 (1986) 377-81.

[2] R.J. Vandebriel, C. Meredith, M.P. Scott, P.J.M. Roholl, H.V. Loveren, Effects of in vivo exposure to bis(tri-n-butyltin)oxide, hexachlorobenzene, and benzo(a)pyrene on cytokine (receptor) mRNA levels in cultured rat splenocytes and on IL-2 receptor protein levels, Toxicol. Appl. Pharmacol. 148 (1997) 126-36.

[3] X.H. Pei, Y. Nakanishi, H. Inoue, K. Takayama, F. Bai, N. Hara, Polycyclic aromatic hydrocarbons induce IL-8 expression through nuclear factor kappaB activation in A549 cell line, Cytokine. 19 (2002) 236-41.

[4] J.C. Will, D.F. Williamson, E.S. Ford, E.E. Calle, M.J. Thun, Intentional weight loss and 13-year diabetes incidence in overweight adults, Am. J. Public. Health. 92 (2002) 1245-8. 
[5] B. Eliasson, Cigarette smoking and diabetes, Prog. Cardiovasc. Dis. 45 (2003) 405-13.

[6] P. Landrigan, A. Garg, D.B. Droller, Assessing the effects of endocrine disruptors in the National Children's Study, Environ. Health Perspect. 111 (2003) 1678-1682.

[7] Y. Tian, A.B. Rabson, M.A. Gallo, Ah receptor and NF-kappaB interactions: mechanisms and physiological implications, Chem. Biol. Interact. 141 (2002) 97-115.

[8] H.M. Lakka, D.E. Laaksonen, T.A. Lakka, L.K. Niskanen, E. Kumpusalo, J. Tuomilehto, J.T. Salonen, The metabolic syndrome and total and cardiovascular disease mortality in middle-aged men, JAMA. 288 (2002) 2709-16.

[9] A.D. Pradhan, J.E. Manson, N. Rifai, J.E. Buring, P.M. Ridker, C-reactive protein, interleukin 6, and risk of developing type 2 diabetes mellitus, JAMA. 286 (2001) 327-334.

[10] L. Capuron, S. Su, A.H. Miller, J.D. Bremner, J. Goldberg, G.J. Vogt, C. Maisano, L. Jones, N.V. Murrah, V. Vaccarino, Depressive Symptoms and Metabolic Syndrome: Is Inflammation the Underlying Link? Biol. Psychiatry. 64 (2008) 831-916.

[11] D. Zozulinska, B. Wierusz-Wysocka, Type 2 diabetes mellitus as inflammatory disease, Diabetes Res. Clin. Pract. 74 (2006) 12-16.

[12] P.D. Cani, J. Amar, M.A. Iglesias, M. Poggi, C. Knauf, D. Bastelica, A.M. Neyrinck, F. Fava, K.M. Tuohy, C. Chabo, A. Waget, E. Delmée, B. Cousin, T. Sulpice, B. Chamontin, J. Ferrières, J.F. Tanti, G.R. Gibson, L. Casteilla, N.M. Delzenne, M.C. Alessi, R. Burcelin, Metabolic endotoxemia initiates obesity and insulin resistance, Diabetes. 56 (2007) 1761-72.

[13] P.D. Cani, R. Bibiloni, C. Knauf, A. Waget, A.M. Neyrinck, N.M. Delzenne, R. Burcelin, Changes in Gut Microbiota Control Metabolic Endotoxemia-Induced Inflammation in High-Fat Diet-Induced Obesity and Diabetes in Mice, Diabetes. 57 (2008) 1470-81.

[14] R. Burcelin, W. Dolci, B. Thorens, Long-lasting antidiabetic effect of a dipeptidyl peptidase IV-resistant analog of glucagon-like peptide-1, Metab. Clin. Exp. 48 (1999) 252-8.

[15] R. Burcelin, V. Crivelli, A. Dacosta, A. Roy-Tirelli, B. Thorens, Heterogeneous metabolic adaptation of C57BL/6J mice to high-fat diet, Am. J. Physiol. Endocrinol. Metab. 282 (2001) E834-42. 
[16] P.D. Cani, C.A. Daubioul, B. Reusens, C. Remacle, G. Catillon, N.M. Delzenne, Involvement of endogenous glucagon-like peptide-1(7-36) amide on glycaemia-lowering oligofructose in streptozotocin-treated rats, J. Endocrinol. 185 (2005) 457-65.

[17] R. Burcelin, V. Crivelli, C. Perrin, A. Da Costa, J. Mu, B.B. Kahn, M.J. Birnbaum, C.R. Kahn, P. Vollenweider, B. Thorens, GLUT4 AMP kinase, but not the insulin receptor, are required for hepatoportal glucose sensor-stimulated muscle glucose utilization, J. Clin. Invest. 111 (2003) 1555-62.

[18] T.D. Schmittgen, K.J. Livak, Analyzing real-time PCR data by the comparative C (T) method, Nat. Protoc. 3 (2008) 1101-8.

[19] J.S Fisler, C.H. Warden, Uncoupling proteins, dietary fat and the metabolic syndrome, Nutr. Metab. 3 (2006) 38.

[20] J.E. Michalek, M. Pavuk, Diabetes and cancer in veterans of Operation Ranch Hand after adjustment for calendar period, days of spraying, and time spent in Southeast Asia, J. Occup Environ. Med. 50 (2008) 330-340.

[21] D. Consonni, A.C. Pesatori, C. Zocchetti, R. Sindaco, L.C. D'Oro, M. Rubagotti, P.A. Bertazzi, Mortality in a Population Exposed to Dioxin after the Seveso, Italy, Accident in 1976: 25 Years of Follow-Up. Am. J. Epidemiol. 167 (2008) 847-858.

[22] D.H. Lee, I.K. Lee, K. Song, M. Steffes, W. Toscano, B.A. Baker, D.R. Jacobs, A strong dose-response relation between serum concentrations of persistent organic pollutants and diabetes: results from the National Health and Examination Survey 1999-2002, Diabetes Care. 29 (2006) 1638-1644.

[23] D.H. Lee, I.K. Lee, M. Steffes, D.R. Jacobs, Extended analyses of the association between serum concentrations of persistent organic pollutants and diabetes, Diabetes Care. 30 (2007) 1596-1598.

[24] S. Carlsson, K. Midthjell, V. Grill, Smoking is associated with an increased risk of type 2 diabetes but decreased risk of autoimmune diabetes in adults: an 11-years follow-up of incidence of diabetes in Nord-Trondelag study, Diabetologia. 47 (2004) 1953-6.

[25] S.G. Wannamethee, A.G. Shaper, I.J. Perry, Smoking as a modifiable risk factor of type 2 diabetes in middle-aged men, Diabetes Care. 24 (2001) 1590-5. 
[26] M. Weitzman, S. Cook, P. Auinger, T.A. Florin, S. Daniels, M. Nguyen, J.P. Winickoff, Tobacco smoke exposure is associated with the metabolic syndrome in adolescents, Circulation. 112 (2005) 862-869.

[27] M.S. Dension, A. Pandini, S.R. Solis, Y. Yang, T.P. Bonati, Ligand binding of and activation of the Ah receptor. Chem. Biol. Interact. 141 (2002) 3-24.

[28] P.M. Fernandez-Salguero, D.M. Hilbert, S. Rudikoff, J.M. Ward, F.J. Gonzalez, Arylhydrocarbon receptor-deficient mice are resistant to 2,3,7,8-tetrachlorodibenzo- $p$-dioxininduced toxicity, Toxicol. Appl. Pharmacol. 140 (1996) 173-179.

[29] F. Fane, B. Yan, G. Wood, M. Viluksela, K.K. Rozman, Cytokines (IL-1 $\beta$ and TNF $\alpha$ ) in relation to biochemical and immunological effects of 2,3,7,8-tetrachlorodibenzo-p-dioxin (TCDD) in rats, Toxicology. 116 (1997) 9-16.

[30] A. Tamaki, H. Hayashi, H. Nakajima, T. Takii, D. Katagiri, M. Miyazawa, K. Hirose, K. Onozaki, Polycyclic aromatic hydrocarbon increases mRNA level for interleukin-1 $\beta$ in human fibroblast-like synoviocyte line via aryl hydrocarbon receptor. Biol. Pharm. Bull. 27 (2004) 407-410.

[31] N.Tsuboyama-Kasaoka, M. Takahashi, H. Kim, O. Ezaki, Up-regulation of liver uncoupling protein-2 mRNA by either fish oil feeding or fibrate administration in mice, Biochem. Biophys. Res. Commun. 257 (1999) 879-85.

[32] K.D. Chavin, S. Yang, H.Z. Lin, J. Chatham, V.P. Chacko, J.B. Hoek, E. Walajtys-Rode, A. Rashid, C.H. Chen, C.C. Huang, T.C. Wu, M.D. Lane, A.M. Diehl, Obesity induces expression of uncoupling protein-2 in hepatocytes and promotes liver ATP depletion, J. Biol. Chem. 274 (1999) 5692-700.

[33] Y. Camara, T. Mampe, J. Armengol, F. Villarroya, L. Dejean, UCP3 expression in liver modulates gene expression and oxidative metabolism in response to fatty acids, and sensitizes mitochondria to permeability transition, Cell. Physiol. Biochem. 24 (2009) 243-52.

[34] R. Stienstra, S. Mandard, D. Patsouris, C. Maass, S. Kersten, M. Müller, Peroxisome proliferator-activated receptor alpha protects against obesity-induced hepatic inflammation, Endocrinology. 148 (2007) 2753-63. 
[35] D. Cai, M. Yuan, D.F. Frantz, P.A. Melendez, L. Hanse, J. Lee, S.E. Shoelson, Local and systemic insulin resistance resulting from hepatic activation of IKK-beta and NF-kappaB, Nat. Med. 11(2005) 183-90.

\section{Figure legends}

Fig.1. Effect of high-fat diet (HFD) versus normal chow diet mice (NC) on relative gene expression levels in the bowel (duodenum, jejunum, ileum and colon) and liver of five-weekold male C57B6/6J mice. *: $p<0.05, * *: p<0.01$. ND: not done, UD: undetected.

Fig.2. Effect of benzo[a]pyrene added to high-fat diet (HFD+BaP) versus high-fat diet mice (NC) on relative gene expression levels in the bowel (duodenum, jejunum, ileum and colon) and liver of five-week-old male C57B6/6J mice. *: $p<0.05$, **: $p<0.01$. ND: not done, UD: undetected.

Fig.3. Effect of HFD or BaP added to HFD on the biochemical data characteristics of type 2 diabetes of five-week-old male C57B6/6J mice. A: Food intake (g) for 5 weeks of treatment. B: Body weight (g). C: glycemia after 5 weeks of dietary treatment were calculated at $-30,0$, 30, 60 and 90 min after glucose injection. D: areas under the curves (AUCs) of glucose tolerance tests calculated from Fig 3, C. Results are mean \pm SD. **: $p<0.01$, ***: $p<0.001$.

\section{Table 1}

\begin{tabular}{|l|l|l|}
\hline Genes & Forward sequence (5'-3') & Reverse sequence (5'-3') \\
\hline$\beta 2$-actin & 5'-AAGGCCAACCGTGAAAAGAT-3' & 5'-TGGTACGACCAGAGGCATAC-3' \\
\hline TNF $\alpha$ & 5'-GGGACAGTGACCTGGACTGT-3' & 5'-TTCGGAAAGCCCATTTGAGT-3' \\
\hline IL-1 $\beta$ & 5'-TCGCTCAGGGTCACAAGAAA-3' & 5'-CATCAGAGGCAAGGAGGAAAA-3' \\
\hline TGF- $\beta$ & 5'-TGGAGCAACATGTGGAACTG-3' & 5'-GTCAGCAGCCGGTTACCA-3' \\
\hline IL-10 & 5'-CACAAAGCAGCCTTGCAGAA-3' & 5'-AGAGCAGGCAGGATAGCAGTG-3' \\
\hline
\end{tabular}




\begin{tabular}{|l|c|c|}
\hline UCP-2 & $5^{\prime}$-CTCCCAATGTTGCCCGTAAT-3' & $5^{\prime}$-GGCTTTCAGGAGAGTATCTTTGA-3' \\
\hline UCP-3 & $5^{\prime}$-GCTGGAGTCTCACCTGTTTACT-3' & 5'-ACAGAAGCCAGCTCCAAAGG-3' \\
\hline GLP-1 & $5^{\prime}$-ACATGCTGAAGGGACCTTTAC-3' & 5'-GGCTTTCACCAGCCAC-3' \\
\hline
\end{tabular}



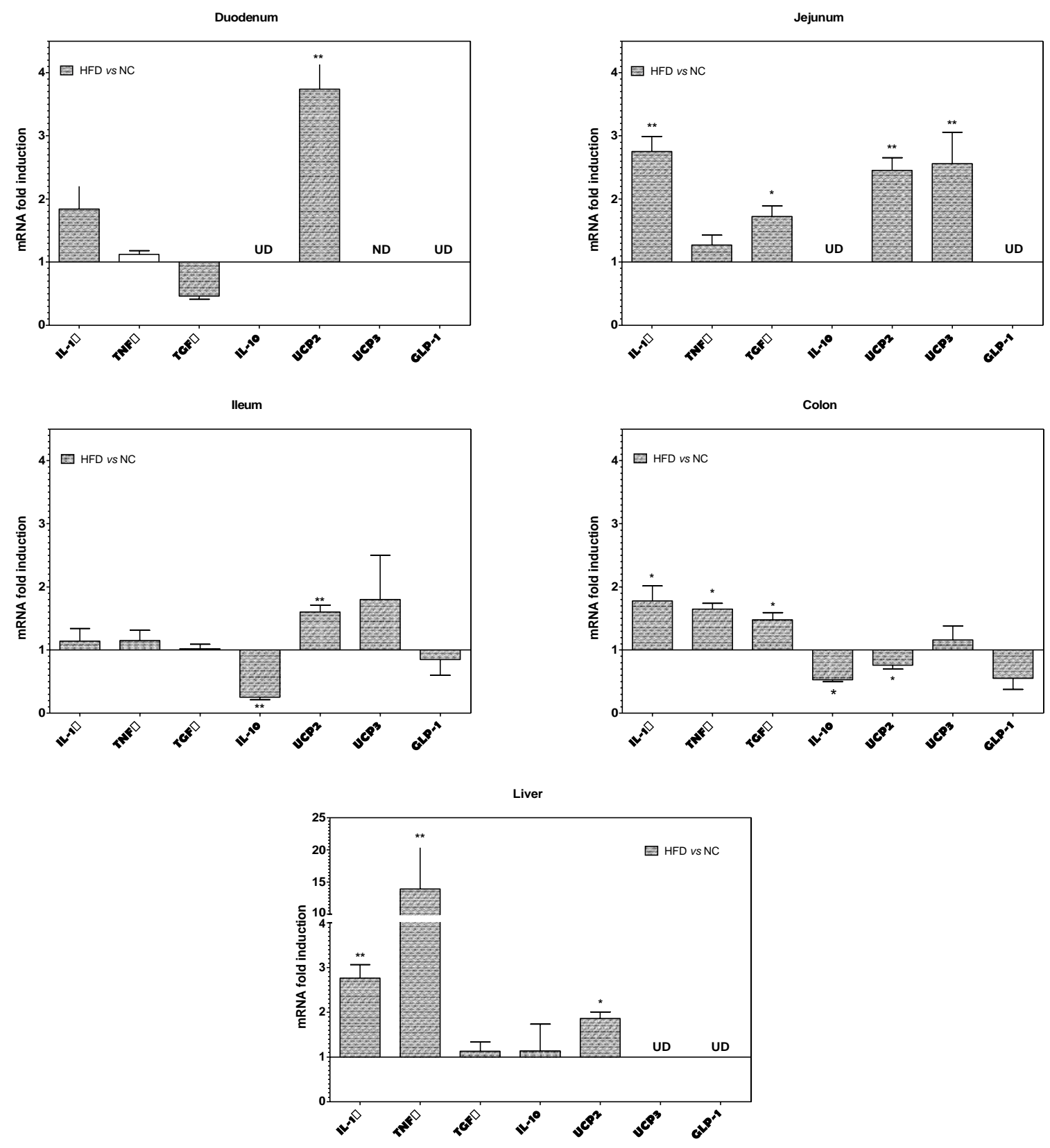

Fig.1. 

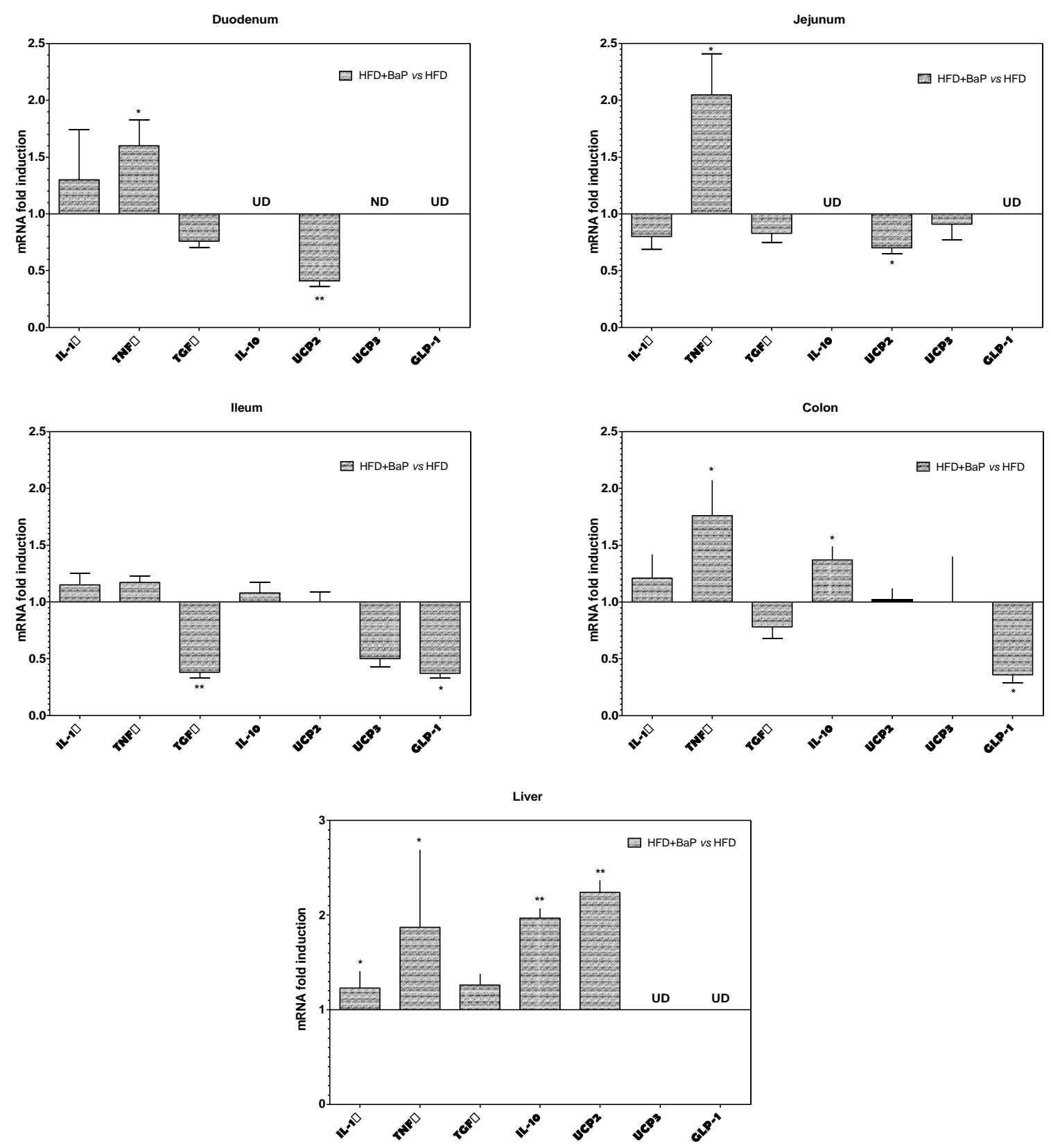

Fig.2. 

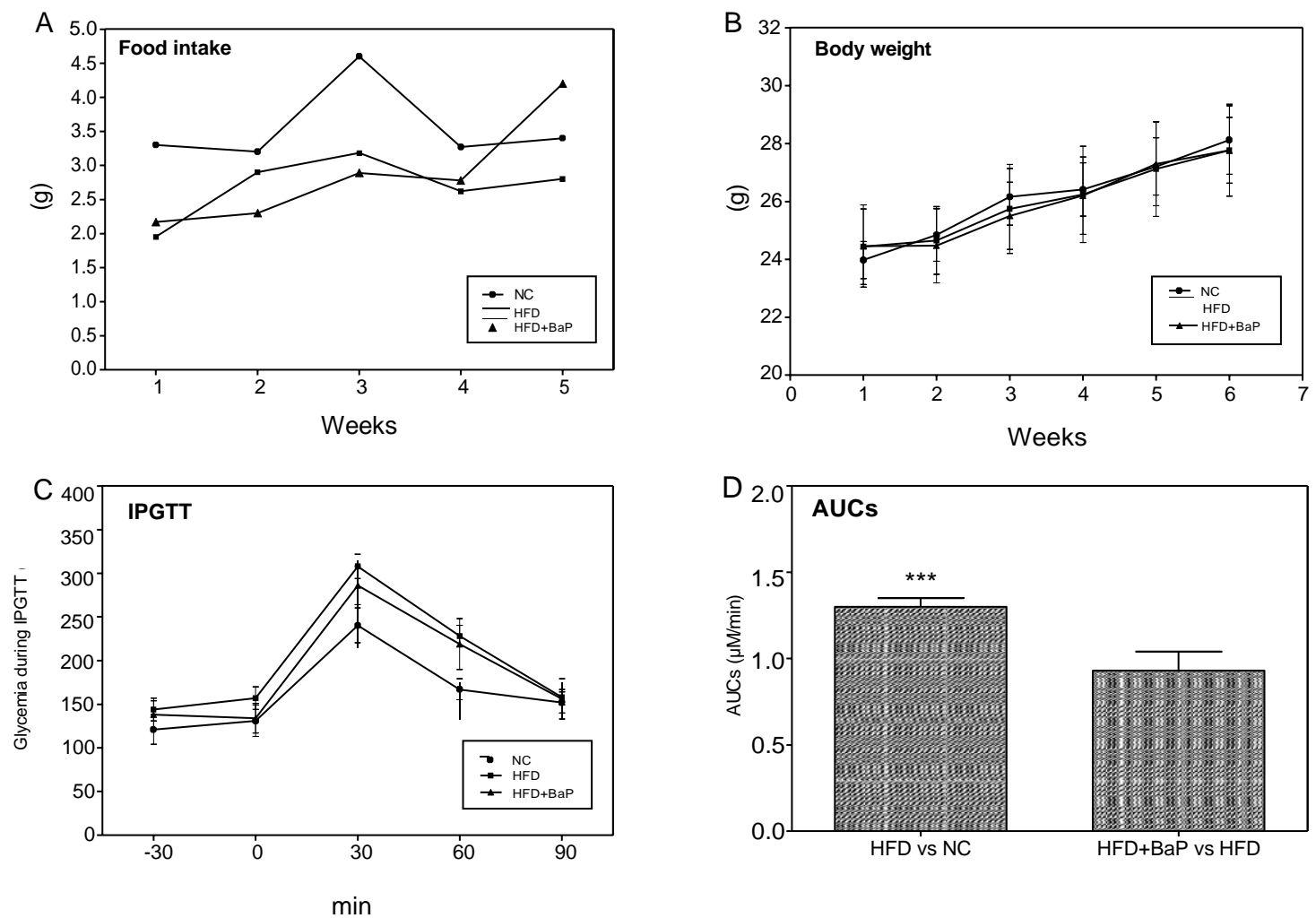

Fig.3. 